\title{
PEFI algal flora: a half-century of investigation
}

\author{
(10) Carlos E. de M. Bicudo ${ }^{1,2}$
}

Received: 15 March 2019; accepted: 14 June 2019

How to cite: Bicudo, C.E.M. 2020. PEFI algal flora: a half-century of investigation. Hoehnea 47: e232019. http://dx.doi. org/10.1590/2236-8906-23/2019.

ABSTRACT - (PEFI algal flora: a half-century of investigation) The survey of the algal flora of the Parque Estadual das Fontes do Ipiranga (PEFI) started in 1962, with the disclosure of occurrence of 17 desmid species, collected from the São Paulo Botanical Gardens hydrophytoterium. However, in an organized way, it took place only 28 years later, in 1990, with the conception of the "Parque Estadual das Fontes do Ipiranga Cryptogamic flora". The flora is essentially based on material gathered from the plankton, periphyton and surface sediments of the PEFI water bodies, and also included samples from trees barks, rocks, and soil. Forty-two fascicles of the algal flora have already been published, revealing 869 taxa including species, varieties and taxonomic formae. It is estimated that $95 \%$ of the local algal flora have already been surveyed and that its conclusion will be reached by the end of the year 2020 .

Keywords: algal flora, floristic survey, taxonomy

RESUMO - (Flora ficológica do PEFI: meio século de estudo). O inventário florístico das algas do Parque Estadual das Fontes do Ipiranga (PEFI) foi iniciado em 1962, com a divulgação da ocorrência de 17 espécies de desmidiáceas, coletadas no hidrofitotério do Jardim Botânico de São Paulo. De modo organizado, entretanto, foi só 28 anos depois, em 1990, resultado da criação da "Flora Criptogâmica do Parque Estadual das Fontes do Ipiranga". A flora está alicerçada em material coletado basicamente do plâncton, perifíton e de sedimentos superficiais de corpos d'água do Parque, mas também incluiu amostras coletadas de troncos de árvores, rochas e solo. Foram publicados até o momento 42 fascículos da flora, em que foram inventariados 869 táxons de algas, incluindo espécies, variedades e formas taxonômicas. Estima-se que $95 \%$ da flora de algas da área já tenha sido inventariada e conjectura-se sua conclusão para o final de 2020.

Palavras-chave: flora ficológica, inventário florístico, taxonomia

\section{Introduction}

First publication dealing with the PEFI, Parque Estadual das Fontes do Ipiranga biota most probably was the third contribution to the knowledge of the Brazilian orchids by Schlechter \& Hoehne (1926), where the authors listed, among others, 13 species for the PEFI area.

Forty-six years elapsed until the publication of the first attempt ever to know the PEFI algal biodiversity. The pioneers, Bicudo \& Bicudo (1962), studied material collected from the hydrophytoterium, an artificial system designed for display of aquatic plants at the São Paulo Botanical Gardens. Seventeen desmid species were there disclosed (Closterium cynthia De Notaris, C. leibleinii Kützing, C. moniliferum (Bory) Ehrenberg, C. navicula (Brébisson) Lütkemuller, $C$. parvulum Nägeli, C. setaceum Ehrenberg, C. venus Kützing, Desmidium cylindricum Greville, Euastrum ansatum Ehrenberg, E. oblongum (Greville) Ralfs, Micrasterias denticulata Brébisson, $M$. laticeps Nordstedt, $M$. rotata (Greville) Ralfs, Pleurotaenium ovatum Nordstedt, P. truncatum (Brébisson) Nägeli, Staurastrum cuspidatum Brébisson and S. erlangense Reinsch) accompanied by description and illustration. Two years later, Bicudo \& Bicudo (1965) continued their inventory identifying more 23 desmid taxa including 16 species and six varieties that are not typical of their respective species, and a taxonomic forma also not typical, but of its respective variety. Closterium gracile Brébisson, C. laterale Nordstedt, C. turgidum Ehrenberg var. giganteum Nordstedt, Cosmarium ocellatum Eichler \& Gutwinski, Desmidium baileyi (Ralfs) Nordstedt f. tetragonum Nordstedt, $D$.

1. Instituto de Botânica, Núcleo de Pesquisa em Ecologia, caixa postal 68041, 04045-972 São Paulo, SP, Brasil

2. Corresponding author: cbicudo@terra.com.br 
swartzii C. Agardh var. amblyodon (Itzigsohn) Rabenhorst, Micrasterias laticeps Nordstedt var. acuminata Krieger, M. pinnatifida (Kützing) Ralfs, M. truncata (Corda) Brébisson var. truncata, $M$. truncata (Corda) Brébisson var. excavata Nordstedt, Sphaerozosma granulatum Roy \& Bisset, Staurastrum inaequale Nordstedt, S. punctulatum Brébisson, $S$. quadrangulare Brébisson var. quadrangulare, $S$. quadrangulare Brébisson var. longispinum Börgesen, $S$. rotula Nordstedt, $S$. trifidum Nordstedt var. tortum (Börgesen) Grönblad and Tetmemorus granulatus (Brébisson) Ralfs) were then identified accompanied by description and illustration for each taxon. Material studied was gathered from artificial tanks, ditches and rain pools located within the PEFI area, without however specified them.

Various other publications followed without, however, any organizing plan. In 1990 the "Flora Criptogâmica do Parque Estadual das Fontes do Ipiranga" (Ipiranga Sources State Park Cryptogamic Flora) was created divided into three sections: (1) algae, (2) fungi and lichens, and (3) bryophytes. The following information summarizes the results from the 28 years devoted to the survey of the PEFI algal flora.

\section{Material and methods}

Study area - Area of present study is the PEFI, Parque Estadual das Fontes do Ipiranga (Ipiranga sources State Park) located in the southeast region of the Municipality São Paulo between parallels $23^{\circ} 38^{\prime} 08^{\prime \prime} \mathrm{S}$ and $23^{\circ} 40^{\prime} 18^{\prime \prime} \mathrm{S}$ and meridians $43^{\circ} 36^{\prime} 48^{\prime \prime} \mathrm{W}$ and $43^{\circ} 36^{\prime} 00^{\prime \prime} \mathrm{W}$. PEFI includes the extension of $526.30 \mathrm{ha}$, and the 24 sources of the Ipiranga Creek, that supply nine reservoirs locally called lakes. Emphasis should be put, because of their size, on the Garças, Cisnes, Ninfeias and IAG reservoirs. For more details concerning the Garças, Ninfeias and IAG reservoirs, please check Bicudo et al. (2002).

Methods - Plankton, periphyton and surface sediments material was basically collected. Plankton samples were gathered using a cone-shaped net made of a $\pm 20 \mu \mathrm{m}$ mesh nylon fabric, that was successively passed as many times as needed in the superficial $30 \mathrm{~cm}$ layer of the water bodies to gather a macroscopically detectable amount of material at the bottom of the flask tied to the end of the net. Samples from levels located below the surface up to near the system bottom, i.e. from the water column were collected using a van Dorn sampler. Periphyton samples were gathered by collecting littoral plant specimens, which were scrapped still in the field or at the laboratory with a razor blade or a brush made of marten's hair, in order to obtain the material more closely adhered to the substrate. Sometimes, plant specimens were manually squeezed to get the material loosely attached to their surface. Algae inhabiting ravines living among bryophytes or ferns were sampled using suction pipets. Rocks, tree trunks and cement walls were also scrapped with a spatula used to remove wall painting to collect enough material for examination. Material inhabiting sediments deposited at reservoir bottoms was collected with a van Dorn sampler. Bicudo \& Menezes (2017) detail all methods mentioned above.

Almost all material collected during the present inventory is deposited at the Instituto de Botânica Herbarium "Maria Eneyda P. Kauffmann Fidalgo" (SP). A few samples were not deposited, because for some reason were lost or damaged during the examination.

\section{List of publications}

Follow in the chronological order, the list of the publications of the "Flora Criptogâmica do Parque Estadual das Fontes do Ipiranga".

Bicudo, C.E.M. 1991. Criptógamos do Parque Estadual das Fontes do Ipiranga, São Paulo, SP. Algas, 1: Chloromonadophyceae. Hoehnea 18(1): 77-85, fig. 1-20.

Castro, A.A.J., Bicudo, C.E.M. \& Bicudo, D.C. 1991. Criptógamos do Parque Estadual das Fontes do Ipiranga, São Paulo, SP. Algas, 2: Cryptophyceae. Hoehnea 18(1): 87-106, fig. 1-90 (1992).

Necchi Júnior, O. \& Bicudo, D.C. 1992. Criptógamos do Parque Estadual das Fontes do Ipiranga, São Paulo, SP. Algas, 3: Rhodophyceae. Hoehnea 19(1-2): 89-92, fig. 1-8.

Picelli-Vicentim, M.M. \& Bicudo, C.E.M. 1993. Criptógamos do Parque Estadual das Fontes do Ipiranga, São Paulo, SP. Algas, 4: Charophyceae. Hoehnea 20(1-2): 9-22, fig. 1-121.

Xavier, M.B. 1994. Criptógamos do Parque Estadual das Fontes do Ipiranga, São Paulo, SP. Algas, 5 Euglenophyceae (Euglenaceae pigmentadas). Hoehnea 21(1-2): 47-73, fig. 1-107.

Sormus, L. \& Bicudo, C.E.M. 1994. Criptógamos do Parque Estadual das Fontes do Ipiranga, São Paulo, SP. Algas, 6: Zygnemaphyceae (Closteriaceae). Hoehnea 21(1-2): 75-92, fig. 1-51. 
Bicudo, C.E.M. 1995. Criptógamos do Parque Estadual das Fontes do Ipiranga, São Paulo, SP. Algas, 7: Prasinophyceae. Hoehnea 22(1-2): 61-75, fig. 1-23. Azevedo, M.T.P., Nogueira, N.M.C. \& Sant'Anna, C.L. 1996. Criptógamos do Parque Estadual das Fontes do Ipiranga, São Paulo, SP. Algas, 8: Cyanophyceae. Hoehnea 23(1): 1-38, fig. 1-158.

Bicudo, C.E.M., Sormus, L. \& Schetty, S.P. 1997. Criptógamos do Parque Estadual das Fontes do Ipiranga, São Paulo, SP. Algas, 9: Zygnemaphyceae (Peniaceae). Hoehnea 24(1): 101-105, fig. 1-6.

Bicudo, C.E.M. \& Sormus, L. 1997. Criptógamos do Parque Estadual das Fontes do Ipiranga, São Paulo, SP. Algas, 10: Zygnemaphyceae (Desmidiaceae, Micrasterias). Hoehnea 24(2): 75-87, fig. 1-23.

Bicudo, C.E.M., Sormus, L. \& Schetty, S.P. 1998. Criptógamos do Parque Estadual das Fontes do Ipiranga, São Paulo, SP. Algas, 11: Zygnemaphyceae (Desmidiaceae, Haplotaenium, Pleurotaenium, Tetmemorus e Triploceras). Hoehnea 25(1): 33-43, fig. 1-16.

Bicudo, C.E.M., Sormus, L. \& Schetty, S.P. 1999. Criptógamos do Parque Estadual das Fontes do Ipiranga, São Paulo, SP. Algas, 12: Zygnemaphyceae (Desmidiaceae 2: Desmidium, Groenbladia, Hyalotheca, Spondylosium e Teilingia). Hoehnea 26(1): 75-85, fig. 1-20.

Bicudo, D.C., Morandi, L.L. \& Ludwig, T.A.V. 1999. Criptógamos do Parque Estadual das Fontes do Ipiranga, São Paulo, SP. Algas, 13: Bacillariophyceae (Eunotiales). Hoehnea 26(2): 173-184, fig. 1-21.

Bicudo, C.E.M. \& Bicudo, D.C. 2001. Criptógamos do Parque Estadual das Fontes do Ipiranga, São Paulo, SP. Algas, 14: Craspedomonadophyceae. Hoehnea 28(1): 21-38, fig. 1-43.

Bicudo, C.E.M. \& Santos, C.I. 2001. Criptógamos do Parque Estadual das Fontes do Ipiranga, São Paulo, SP. Algas, 15: Chlorophyceae (Trentepohliales). Hoehnea 28(3): 183-190, fig. 1-13.

Bicudo, C.E.M. \& Pereira, F.C. 2003. Criptógamos do Parque Estadual das Fontes do Ipiranga, São Paulo, SP. Algas, 16: Chlorophyceae (Ulotrichales). Hoehnea 30(1): 31-37, fig. 1-12.

Bicudo, C.E.M., Bicudo, D.C., Ferragut, C., Lopes, M.R.M. \& Pires, P.R. 2003. Criptógamos do Parque Estadual das Fontes do Ipiranga, São Paulo, SP. Algas, 17: Chrysophyceae. Hoehnea 30(2): 127-153, fig. 1-103.

Bicudo, C.E.M. 2004. Criptógamos do Parque Estadual das Fontes do Ipiranga, São Paulo, SP. Algas, 18: Chlorophyceae (Volvocales). Revista Brasileira de Botânica 27(1): 85-102, fig. 1-41.
Bicudo, D.C., Oliveira, A.M., Ferragut, C. \& Bicudo, C.E.M. 2006. Criptógamos do Parque Estadual das Fontres do Ipiranga, São Paulo, SP. Algas, 19: Eustigmatophyceae. Hoehnea 31(2): 97-101, fig. 1-8. Morandi, L.L., Ritter, L.M.O., Moro, R.S. \& Bicudo, C.E.M. 2006. Criptógamos do Parque Estadual das Fontes do Ipiranga, São Paulo, SP. Algas, 20: Coscinodiscophyceae. Hoehnea 33(1): 115-122, fig. 1-19.

Bicudo, D.C., Bicudo, C.E.M., Oliveira, A.M., Ferragut, C., Fonseca, B.M., Lopes, M.R.M. \& Lima, I.R.N. 2006. Criptógamos do Parque Estadual das Fontes do Ipiranga, São Paulo, SP. Algas, 21: Xanthophyceae. Hoehnea 33(3): 291-316, fig. 1-66. Araújo, A. \& Bicudo, C.E.M. 2006. Criptógamos do Parque Estadual das Fontes do Ipiranga, São Paulo, SP. Algas, 22: Zygnemaphyceae (gêneros Actinotaenium, Cosmarium e Heimansia). Hoehnea 33(2): 219-237, fig. 1-30.

Elkis, I.C. \& Bicudo, C.E.M. 2006. Criptógamos do Parque Estadual das Fontes do Ipiranga, São Paulo, SP. Algas, 23: Oedogoniophyceae. Hoehnea 33(4): 511-520, fig. 1-19.

Bicudo, C.E.M., Faustino, S.M.M., Godinho, L.R. \& Oliveira, M. 2007. Criptógamos do Parque Estadual das Fontes do Ipiranga, São Paulo, SP. Algas, 24: Zygnemaphyceae (Desmidiales: Octacanthium, Staurastrum e Saurodesmus). Hoehnea 34(4): 497-517, fig. 1-31.

Rocha, A.C.R. \& Bicudo, C.E.M. 2008. Criptógamos do Parque Estadual das Fontes do Ipiranga, São Paulo, SP. Algas, 25: Bacillariophyceae (Naviculales, Pinnulariaceae). Hoehnea 35(4): 597-618, fig. 1-52. Fernandes, S. \& Bicudo, C.E.M. 2009. Criptógamos do Parque Estadual das Fontes do Ipiranga, São Paulo, SP. Algas 26: Chlorophyceae (famílias Chlorococcaceae e Coccomyxaceae). Hoehnea 36(1): 173-191, fig. 1-48, tab. 1-2.

Bicudo, C.E.M. 2010. Criptógamos do Parque Estadual das Fontes do Ipiranga, São Paulo, SP. Algas, 27: Euglenophyceae (famílias Petalomonadaceae e Scytomonadaceae). Hoehnea 37(2): 331-335, fig. 1-3. Bicudo, C.E.M. 2010. Criptógamos do Parque Estadual das Fontes do Ipiranga, São Paulo, SP. Algas, 28: Euglenophyceae (família Eutreptiaceae). Hoehnea 37(2): 377-381, fig. 1-4.

Bicudo, C.E.M. 2010. Criptógamos do Parque Estadual das Fontes do Ipiranga, São Paulo, SP. Algas, 29: Euglenophyceae (família Peranemaceae). Hoehnea 37(2): 383-402, fig. 1-37. 
Godinho, L.R., Comas-Gonzáles, A. \& Bicudo, C.E.M. 2010. Criptógamos do Parque Estadual das Fontes do Ipiranga, São Paulo, SP. Algas, 30: Chlorophyceae (família Scenedesmaceae). Hoehnea 37(3): 513-553, fig. 1-123.

Bicudo, C.E.M. 2011. Criptógamos do Parque Estadual das Fontes do Ipiranga, São Paulo, SP. Algas, 31: Euglenophyceae (Euglenaceae não pigmentadas). Hoehnea 38(1): 31-36, fig. 1-5.

Bicudo, C.E.M. 2011. Criptógamos do Parque Estadual das Fontes do Ipiranga, São Paulo, SP. Algas, 32: Dinophyceae (famílias Dinococcaceae, Gymnodiniaceae e Hemidiniaceae). Hoehnea 38(1): 97-108, fig. 1-24.

Bicudo, C.E.M. 2012. Criptógamos do Parque Estadual das Fontes do Ipiranga, São Paulo, SP. Algas, 33: Chlorophyceae (famílias Palmellaceae, Hormotilaceae e Dictyosphaeriaceae). Hoehnea 39(4): 565-575, fig. 1-16.

Tucci, A., Bento, N.R.M., Rosal, C. \& Bicudo, C.E.M. 2014. Criptógamos do Parque Estadual das Fontes do Ipiranga, São Paulo, SP. Algas, 34: Chlorophyceae (Golenkiniaceae e Micractiniaceae). Hoehnea 41(2): 307-314, fig. 1-9.

Bicudo, C.E.M. 2013. Criptógamos do Parque Estadual das Fontes do Ipiranga, São Paulo, SP. Algas, 35: Dinophyceae (família Peridiniaceae). Hoehnea 40(4): 611-617, fig. 1-5.

Marquardt, G.C. \& Bicudo, C.E.M. 2014. Criptógamos do Parque Estadual das Fontes do Ipiranga, São Paulo, SP. Algas, 36: Bacillariophyceae (Cymbellales). Hoehnea 41(2): 209-246, fig. 1-194.

Bicudo, C.E.M. \& Bicudo, D.C. 2014. Criptógamos do Parque Estadual das Fontes do Ipiranga, São Paulo, SP. Algas, 37: Chlorophyceae (Chaetophorales). Hoehnea 41(3): 411-422, fig. 1-31.

Bicudo, C.E.M. 2014. Criptógamos do Parque Estadual das Fontes do Ipiranga, São Paulo, SP. Algas, 38: Chlorophyceae (Tetrasporales e Siphonocladales). Hoehnea 41(3): 337-343, fig. 1-10.

Loaiza-Restado, A.M. \& Bicudo, C.E.M. 2014. Criptógamos do Parque Estadual das Fontes do Ipiranga, São Paulo, SP. Algas, 40: Chlorophyceae (Hydrodictyaceae). Hoehnea 41(3): 353-364, fig. 1-12. Tucci, A., Sawatani, M., Rosini, E.F., Lopes, R.I. \& Bicudo, C.E.M. 2015. Criptógamos do Parque Estadual das Fontes do Ipiranga, São Paulo, SP. Algas, 41: Chlorophyceae (Oocystaceae). Hoehnea 42(3): 603-614, fig. 1-15.
Ferreira, K.S.M. \& Bicudo, C.E.M. 2017. Criptógamos do Parque Estadual das Fontes do Ipiranga, São Paulo, SP. Algas, 42: Bacillariophyceae (Surirellales). Hoehnea 44(1): 10-28, fig. 1-35, tab. 1.

\section{Final remarks}

Except for fascicle 18 that encompassed the Volvocales (Chlorophyceae) published in the "Revista Brasileira de Botânica" (today "Brazilian Journal of Botany"), all other fascicles were published in "Hoehnea", that was the journal established for publication of the "Flora Ficológica do PEFI" (PEFI Algal Flora). Forty-two fascicles were already published and it is expected that the flora will be completed towards the end of year 2020. Below (table 1) with the list of groups already studied and the number of taxa identified for each one.

Table 1. List of taxonomic groups (classes) studied and the respective number of taxa identified (species, varieties, and taxonomic formae) for each group.

\begin{tabular}{lc}
\hline Taxonomic group & Number of táxons \\
\hline Bacillariophyceae $(*)$ & 115 \\
Charophyceae & 5 \\
Chlorophyceae $(*)$ & 172 \\
Chrysophyceae & 51 \\
Craspedomonadophyceae & 23 \\
Cryptophyceae & 21 \\
Cyanobacteria & 86 \\
Dinophyceae & 32 \\
Euglenophyceae & 99 \\
Eustigmatophyceae & 5 \\
Oedogoniophyceae & 15 \\
Prasinophyceae & 21 \\
Raphidophyceae & 8 \\
Rhodophyceae & 2 \\
Xanthophyceae & 47 \\
Zygnematophyceae & 167 \\
\hline Total & 869 \\
\hline
\end{tabular}

(*) Group still incompletely studied.

Survey of the PEFI freshwater algae is practically completed. It includes over 50 years of random samplings accomplished in the PEFI water bodies. The collection was made in nine reservoirs (Garças, Ninfeias, IAG, Cisnes, Bambus I, Bambus II, Bugios, Monjolo and Girinos) locally called "lakes", the hydrophytoterium (a place for exhibition of aquatic plants in the São Paulo 
Botanical Gardens), and a creek (Pirarungáua Creek). All those places were visited randomly more than once and some of them (Garças, Ninfeias, and IAG) during successive months in the case of ecology projects. About 1,000 sample units were gathered during the 57 years duration of present inventory. It is still missing, however, the survey of the Radiococcaceae (Chlorophyceae), and from the Bacillariophyta are already ready the Coscinodiscophyceae and from the Bacillariophyceae, the Eunotiaceae, Pinnulariaceae, Cymbellales, Surirellales, and Rhopalodiales. Consequently, all other diatom groups are until now missing.

Nine hundred and eighty-six samples were already collected for the present survey. Ninfeias Lake was the PEFI most visited place, with 327 samples. Follow the Garças Lake with 177 samples, the hydrophytoterium with 157, and the IAG Lake with 152 samples collected. Ninfeias Lake also is the system that encompassed the largest number of taxa identified, followed by Garças Lake. The hydrophytoterium comes in the third place, but it is a very much handled system, to the point that we do not know anymore its real floristic composition.

Plankton material (423) represents the largest number of samples, followed by periphyton (294), benthos (54), and the surface sediments (28). A sampling of soil material, epiphyton, tree trunks, and epilithon was also carried out in a smaller, but appropriate scale. It is very important to comment that gathering of periphytic material contributed to the knowledge with approximately $40 \%$ of total PEFI's inventoried taxa, which would not be inventoried if only plankton material was collected. Another kind of sample that contributed significantly to the survey of the PEFI algal flora, mostly of the diatoms and non-pigmented euglenoids, was that of reservoirs' surface sediments.

Sixteen algal classes had representatives documented for the PEFI area. There are presently surveyed 869 taxa, including species, varieties, and taxonomic formae. We believe that c. $95 \%$ of all taxa occurring in the PEFI area was already inventoried. Chlorophyceae are the richest group in terms of number of species. Addition of the Radiococcaceae to the total number of taxa will certainly be very small. Following, are the Zygnematophyceae with 167 taxa, whose survey is already concluded for the PEFI area. In the third place, are the Bacillariophyceae with 115 taxa, but this number for sure does not represent the participation of this algal group in the total number of taxa identified for the Park. Chlorophyceae includes a high number of genera, however, just a few of them with a high number of species. Zygnematophyceae do not include as many genera as the Chlorophyceae, but two of them (Cosmarium and Staurastrum) presented a high number of species in the Park, making high the class total number of taxa. The Bacillariophyceae surely includes the World largest number of taxa, and that considerable species-rich groups are still to be surveyed.

The highest species, varieties and taxonomic formae numbers identified during this research called our attention. However, it may be explained first because of the enormous sampling effort represented by more than 50 years of intensive gathering. Duration of the sampling period surely implies the identification of a higher number of taxa. During the present survey, besides the sampling effort, obviously also interfered with the PEFI high taxonomic richness the sampling in the different water bodies compartments represented by the investigation of the plankton, periphyton and the surface sediments of semilentic systems (reservoirs). The last two compartments contributed nearly $40 \%$ to the total number of taxa of present flora. The scenery above undoubtedly led to the inventory of the most complete freshwater algal flora ever carried out in Brazil.

\section{Acknowledgments}

A flora is not one-man product. It is team work. Our most sincere thanks to the 20 professional researchers and the 19 students that helped materialization up to now of the "PEFI Algal Flora".

\section{Literature cited}

Bicudo, C.E.M. \& Bicudo, R.M.T. 1962. Contribuição ao conhecimento das Desmidiaceae do Parque do Estado, S. Paulo. Rickia 1: 207-225, pl. 1-5.

Bicudo, C.E.M. \& Bicudo, R.M.T. 1965. Contribuição ao conhecimento das Desmidiaceae do Parque do Estado, São Paulo, 2. Rickia 2: 39-54, pl. 1-3.

Bicudo, C.E.M., Carmo, C.F., Bicudo, D.C., Henry, R., Pião, A.C.S., Santos, C.M. \& Lopes, M.R.M. 2002. Morfologia e morfometria de três reservatórios do PEFI. In: D.C. Bicudo, M.C. Forti \& C.E.M. Bicudo (orgs.). Parque Estadual das Fontes do Ipiranga: Unidade de Conservação que resiste à urbanização de São Paulo. Secretaria do Meio Ambiente do Estado de São Paulo, São Paulo. pp. 143-160.

Bicudo, C.E.M. \& Menezes, M. 2017. Gêneros de algas de águas continentais do Brasil: chave para identificação e descrições. 3 ed. Editora RiMa, São Carlos.

Schlechter, R. \& Hoehne, F.C. 1926. Contribuições ao conhecimento das Orchidáceas do Brasil (Beiträge zur Orchideenkunde Brasiliens), 3. Arquivos de Botanica do Estado de São Paulo 1: 159-349, pl. 1-26. 